\title{
DAMPAK MEDIA ONLINE TERHADAP AKTIVITAS BELAJAR ANAK DI LUAR SEKOLAH PADA ANAK USIA SEKOLAH MENENGAH PERTAMA
}

\author{
Misran Rahman \\ Universitas Negeri Gorontalo \\ misran@ung.ac.id
}

\begin{abstract}
Abstrak.
Penelitian ini bertujuan untuk memberikan gambaran mengenai dampak media online terhadap aktivitas belajar siswa SMP di luar sekolah, di mana pengaruh media online yang pesat sangat tidak terkontrol dan dikhawatirkan akan memberikan dampak negatif bagi pengguna terutama generasi muda. Untuk mendapatkan hasil, penelitian ini menggunakan metode deskriptif kualitatif - kuantitatif dengan analisis persentase serta analisis statistik. Penelitian ini dilaksanakan terhadap sekelompok anak SMP yang bertempat tinggal di Gorontalo sebanyak 50 orang. Hasil menunjukkan bahwa media online mengganggu konsentrasi belajar anak. Namun, mengingat banyaknya manfaat penggunaan media online, pendampingan orang tua diperlukan dalam mengontrol aktivitas online anak. Hal ini melibatkan kesadaran serta pemahaman orang tua mengenai media online.
\end{abstract}

Kata kunci: Media online, aktivitas belajar, luar sekolah, siswa SMP

\begin{abstract}
.
This study aims to provide an overview of the impact of online media on learning activities of junior high school students outside of school. The rapid influence of online media is very uncontrolled and it is feared that it will have a negative impact on users, especially the younger generation. To get the results, the research used descriptive qualitative - quantitative methods with proportion analysis and statistical analysis. This research was conducted on a group of 50 junior high school children residing in Gorontalo. The results show that online media interfere with children's learning. However, given the use of online media, parental assistance is needed in controlling children's activities. This involves parents' awareness and understanding of online media.
\end{abstract}

Keywords: Online media, learning activities, outside school, junior high school students

\section{PENDAHULUAN}

Ketika pergerakan peradaban semakin pesat, di mana manusia saling berkompetisi menjadi yang terdepan, tingkat efektifitas dan efisiensi teknologi pun menjadi tuntutan. Akibatnya, kemajuan teknologi serta pesatnya informasi menjadi dampak yang tak terhindarkan. Konektivitas jaringan, misalnya, tidak hanya sebatas menyambungkan suara atau berkirim pesan singkat, tapi kini menjadi wahana yang lebih besar, seperti sharing berita (Kumar dkk, 2018), sarana jualan (Sreejesh, 2020), bahkan hingga mempengaruhi aktivitas politik (Papakyriakopoulos dkk, 2019). Pesatnya sebaran informasi bahkan juga membantu deteksi dini bencana (Fana dkk, 2020)

Meski jelas bahwa perkembangan teknologi ditujukan untuk manusia, remaja saat ini yang 'kecanduan' media sosial cenderung mengalami gangguan fisik dan psikologis (Woods dan Scoot, 2016; Fu dkk., 2020; Fang dkk., 2020). Pada akhirnya, penggunaan media sosial bergantung pada kesadaran diri masing-masing.

Bagaimana dengan kegiatan belajar online? Penggunaan media sosial dalam kegiatan pembelajaran tergantung pada kesukaan dan kebutuhan setiap warga belajar. Siswa dengan latar belakang paruh waktu, misalnya, lebih memilih pembelajaran online karena lebih fleksibel. 
Sedangkan orang tua, dengan pemahaman teknologi yang terbatas, memilih pembelajaran tradisional di kelas karena lebih mudah (Knapke dkk., 2016).

Penelitian ini dilakukan di Desa Talango, Kecamatan Kabila, Kabupaten Bone Bolango, Provinsi Gorontalo, dengan tujuan untuk memberikan gambaran tentang penggunaan media sosial untuk kegiatan belajar siswa SMP. Dari hasil observasi peneliti di Desa Talango, Kecamatan Kabila, Kabupaten Bone Bolango, Provinsi Gorontalo, diperoleh data jumlah siswa usia SMP (usia 12-16 tahun) sebanyak 134 siswa. Sebanyak 85 dari mereka bersekolah di sekolah menengah pertama, dengan 15 di antaranya tidak tamat sekolah menengah pertama. 50 dari 85 siswa kemudian diambil, karena jumlah siswa ini memiliki Smartphone. Kepemilikan Smartphone cenderung meningkatkan kecenderungan kecanduan media sosial (Macmud, 2018).

\title{
METODE PENELITIAN
}

Pendekatan yang digunakan dalam penelitian ini adalah pendekatan kuantitatif dan kualitatif, dengan metode analisis deskriptif. Teknik pengumpulan data dengan angket dan wawancara. Siswa yang mengisi angket direncanakan 50 siswa. Untuk mendukung hasil penelitian, dilakukan wawancara dengan orang tua siswa dan guru di sekolah.

Teknik analisis data menggunakan analisis persentase dan analisis komparatif. Data yang dianalisis adalah hasil angket yang terdiri dari 3 jenis angket, yaitu: (i) angket penggunaan media sosial, (ii) angket aktivitas pembelajaran dan (iii) angket respon siswa terhadap penggunaan media sosial dan angket respon terhadap pembelajarannya. kegiatan. Penulis menggunakan aplikasi SPSS Statistics untuk mengolah beberapa jenis data.

Kami mendefinisikan aplikasi berikut -Facebook, Instagram, WhatsApp, Tiktok- sebagai media sosial (mengacu pada Adams, 2019)

\section{HASIL DAN PEMBAHASAN}

\begin{abstract}
Akses Media Online
Aspek pertama menilai kemampuan anak dalam mengakses media online. Pengetahuan ini dapat digambarkan dari berapa banyak akun media sosial yang dimiliki anak dan seberapa sering mereka menggunakannya. 42 dari 50 responden dibagi menjadi mengirimkan hasilnya pada aspek media online. terangkum bahwa aplikasi media online yang diakses anak antara lain WhatsApp (WA), Instagram, Facebook, Tik Tok, Snapchat, video, dan game online. Sebanyak lebih dari $20 \%$ responden mampu mengakses tiga aplikasi media sosial atau lebih. Bahkan semua anak mampu mengakses WhatsApp (WA) (Tabel 1). WhatsApp merupakan media online yang sangat sering diakses oleh anak SMP (sebesar 78,57\%). Hal ini dikarenakan whatsapp mempermudah komunikasi antar siswa dan guru dalam grup (Kilis dan Yildirim, 2019). Selanjutnya, total penggunaan media durasi $1-2$ jam sekitar 42,85\% dan sekitar 28,57 untuk mengakses media online kurang dari satu jam. Dengan melihat durasi waktu yang digunakan anak dalam mengakses media online maksimum 2 jam dalam sehari maka dapat diinterpretasi bahwa hal ini masih tergolong wajar. Anak masih berupaya menyisakan waktu untuk kegiatan lain, misalnya belajar, kerja PR atau kegiatan lain yang bermanfaat. Demikian pula dengan jenis media online yang sering diakses sebagian besar anak adalah WhatsApp (WA) hal ini menunjukkan bahwa jenis media online yang digunakan masih tergolong sederhana. Momen anak mengakses media online lebih banyak pada saat santai, sekitar 35,71\% (Tabel 2). Namun demikian masih terdapat 33,33\% anak mengakses media online setiap hari. Sementara itu ada sekitar 26,19\% anak mengakses online nanti pada saat ada notifikasi.
\end{abstract}


Seminar Nasional Penelitian dan Pengabdian kepada Masyarakat Universitas Sang Bumi Ruwa Jurai Tahun 2020

Tabel 1. Frekuensi dan durasi waktu akses media online

\begin{tabular}{|c|c|c|c|c|c|}
\hline \multirow{2}{*}{ Media Sosial } & \multicolumn{4}{|c|}{ Waktu Mengakses (per hari) } & \multirow{2}{*}{ Total $(\%)$} \\
\hline & $<1$ jam & 1 - 2 jam & 3 - 4 jam & $>4$ jam & \\
\hline WA $(\%)$ & 21,43 & 33,33 & 16,67 & 7,14 & 71.43 \\
\hline $\mathrm{FB}(\%)$ & 2,38 & 4,76 & 0 & 2,38 & 9.52 \\
\hline $\mathrm{IG}(\%)$ & 2,38 & 2,38 & 0 & 2,38 & 7.14 \\
\hline Tiktok $(\%)$ & 2,38 & 2,38 & 0 & 0 & 4.76 \\
\hline Total $(\%)$ & 28.57 & 42.85 & 16.67 & 4.76 & \\
\hline
\end{tabular}

Tabel 2. Momen akses media online

\begin{tabular}{ccccc}
\hline \multirow{2}{*}{ Media Sosial } & \multicolumn{4}{c}{ Momen akses } \\
\cline { 2 - 5 } & Setiap saat & Saat Belajar & Saat notifikasi & Saat santai \\
\hline WA (\%) & 23,81 & 4,76 & 23,81 & 26,19 \\
FB (\%) & 4,76 & 0 & 2,38 & 2,38 \\
IG (\%) & 4,76 & 0 & 0 & 2,38 \\
Tiktok (\%) & 0 & 0 & 0 & 4,76 \\
\hline
\end{tabular}

\begin{abstract}
Aktivitas Belajar
Pemberlakuan kurikulum 2013 di provinsi Gorontalo termasuk SMP menerapkan sistem belajar lima hari seminggu. Sementara itu kegiatan kurikuler menuntut anak SMP berada di sekolah selama 38 Jam pelajaran dalam seminggu belum termasuk kegiatan gerakan literasi sekolah dan penguatan pendidikan karakter. Sehingga total waktu belajar anak seminggu, selama 1710 menit ditambah waktu pra pembelajaran 75 menit, istirahat pagi menjelang siang 75 menit setiap hari, dan istirahat siang sekitar 330 menit (hari Jumat 90 menit). Jadi total waktu anak berada di sekolah dalam seminggu adalah 2190 menit atau setara dengan 36,5 jam. Jika dirataratakan maka setiap hari anak berada di sekolah selama 7 jam 18 menit. Dengan demikian ratarata jam keluar anak SMP sekitar pukul 14.00 (apel pagi pukul 07.00). Hasil kuisioner 46 dari 50 responden, menunjukkan perbedaan waktu anak tiba di rumah disebabkan antara lain jarak sekolah dengan rumah yang bervariasi (Tabel 3). Setelah ditelusuri jarak antara sekolah dengan tempat tinggal anak minimal $3 \mathrm{~km}$. sebagian besar anak menggunakan angkutan umum setelah pulang dari sekolah.
\end{abstract}

Tabel 3. Keberdadaan anak di rumah

\begin{tabular}{ccc}
\hline Waktu (pukul) & Frekuensi & $\boldsymbol{\%}$ \\
\hline$<15.00$ & 21 & 45,65 \\
$15.00-16.00$ & 23 & 50,00 \\
$>16.00$ & 2 & 4,35 \\
\hline Jumlah & 46 & \\
\hline
\end{tabular}

Namun demikian, semua siswa melaksanakan kegiatan mengulangi kembali mata pelajaran dari sekolah meskipun dengan kualitas yang berbeda (Tabel 4). Meskipun sebagian besar respoden jarang melakukan kegiatan "mengulangi materi dari sekolah" tersebut. Ada kecenderungan pada anak untuk menggunakan smartphone sebagai wadah menyimpan materi pelajaran. Sehingga jika 
ada waktu luang di tempat-tempat tertentu dapat digunakan untuk membaca materi. Dari data di atas nampak bahwa sebagian besar anak melakukan penyimpanan. Tebukti hanya seorang responden yang tidak melakukan hal itu. Nampak pula bahwa lebih dari $60 \%$ anak minimal sering melakukan kegiatan tersebut secara baik.

Tabel 4. Deskripsi Aktivitas Belajar Siswa Di Luar Sekolah

\begin{tabular}{ccccc}
\hline $\begin{array}{c}\text { Aktivitas } \\
\text { Belajar }\end{array}$ & Selalu & Sering & Jarang & $\begin{array}{c}\text { Tidak } \\
\text { Pernah }\end{array}$ \\
\hline $\begin{array}{c}\text { Mengulang } \\
\text { materi (\%) }\end{array}$ & 13.04 & 32.61 & 54.35 & 0 \\
Bekerja PR (\%) & 60,87 & 19,57 & 19,57 & 0 \\
Membaca referensi lain (\%) & 23,91 & 39,13 & 34,78 & 2,17 \\
Belajar Kelompok (\%) & 30,43 & 43,48 & 23,81 & 2,17 \\
$\begin{array}{c}\text { Menyimpan materi pada } \\
\text { smartphone (\%) }\end{array}$ & 26,09 & 36,96 & 34,78 & 2,17 \\
\hline
\end{tabular}

Selanjutnya untuk kegiatan mengerjakan pekerjaan rumah, sebagian besar taat mengerjakan PR tersebut. Untuk kegiatan membaca referensi selain dari buku yang disiapkan sekolah nampak bahwa sebagian besar (lebih dari 60\%) melakukan kegiatan tersebut. Yang tidak membaca referensi hanya 1 orang $(2,17 \%)$. Demikian pula dengan aktivitas belajar kelompok nampak sebagian besar anak (lebih dari 70\%) melakukan kegiatan tersebut. Yang tidak ikut dalam kerja kelompok ada 1 orang $(2,17 \%)$.

Secara umum anak melakukan empat aspek aktivitas belajar di luar sekolah dengan baik. Hal ini ikut mendukung peningkatan prestasi belajarnya di sekolah. Dari table 4 tersebut nampak bahwa sebagian besar anak melakukan 4 kegiatan aktivitas belajar di luar sekolah sebagaimana dikemukakan di atas dengan predikat minimal sering. Hal ini menunjukkan bahwa sebagian besar anak melakukan aktivitas belajar di luar sekolah secara baik. Hasil ini sependapat dengan Kaplan (2010) mengenai pemanfaatan sosial.

Tabel 5. Deskripsi Aktivitas Belajar Siswa Di Luar Sekolah

\begin{tabular}{ccccc}
\hline $\begin{array}{c}\text { Aktivitas } \\
\text { Belajar }\end{array}$ & $<\mathbf{1}$ Jam & $\mathbf{1}-\mathbf{2}$ jam & $\mathbf{2}-\mathbf{3}$ jam & $>\mathbf{3}$ jam \\
\hline $\begin{array}{c}\text { Mengulang } \\
\text { materi }\end{array}$ & 60,87 & 34.78 & 0 & 4,35 \\
\hline Belajar Kelompok & 30,43 & 43,48 & 13,04 & 13,04 \\
\hline $\begin{array}{c}\text { Mengulang materi } \\
\text { melalui smartphone }\end{array}$ & 45,65 & 47,83 & 2,17 & 4,35 \\
\hline
\end{tabular}

Waktu yang digunakan siswa melaksanakan kegiatan mengulangi kembali mata pelajaran dari sekolah cukup bervariasi (Tabel 5). Terbanyak siswa melakukannya paling tinggi 2 jam. Hanya 2 orang dari responden yang melaksanakan lebih dari 3 jam. Sementara, kecenderungan anak untuk menggunakan smartphone bahkan mengurangi durasi waktu tidur di malam sesuai pemaparan Cleland dkk (2016) sangatlah mungkin terjadi. Walaupun tidak mengakibatkan stress akut seperti pemaparan Johnshoy dkk (2018), bukanlah satu hal yang positif bagi siswa jika lebih 
sering menggunakan smartphone dibandingkan menggunakan buku. Misalnya, dengan adanya gadget, anak cenderung untuk mengabaikan sekitarnya (Fang dkk, 2020). Terakhir untuk kerja kelompok, waktu yang digunakan paling lama 2 jam. Meskipun terdapat siswa bertahan belajar kelompok hingga lebih dari 3 jam. Hasil ini menunjukkan bahwa media online tidak begitu mengganggu pembelajaran anak. Sebaliknya, adanya media online cukup membantu anak dalam pembelajaran.

\section{Respon Anak Terhadap Media Online dan Pemanfatannya}

Respon anak dibagi dalam dua aspek, yaitu: (a) Respon terhadap media online, dan (b) respon terhadap pemanfaatan media online dalam pembelajaran. Hasil analisis terhadap respon anak terhadap pelaksanaan kedia online dilakukan dengan jalan membandingkan rata-rata skor respon hasil kuesioner dengan rata-rata skor respon netral. Selanjutnya perbandingan antara skor tersebut dianalisis melalui uji statistik.

Deskripsi umum data skor respon anak terhadap media online dan data respon terhadap pemanfaatan media online nampak pada tabel 6 berikut:

Table 6. Deskripsi skor respon anak terhadap media online dan pemanfaatannya dalam pembelajaran

\section{Paired Samples Statistics}

\begin{tabular}{|c|c|c|c|c|c|}
\hline & & Mean & $N$ & $\begin{array}{c}\text { Std. } \\
\text { Deviation }\end{array}$ & $\begin{array}{l}\text { Std. Error } \\
\quad \text { Mean }\end{array}$ \\
\hline \multirow{2}{*}{$\begin{array}{c}\text { Pair } \\
1\end{array}$} & Skor Observasi Media Online & 2.7850 & 6 & .74471 & .30403 \\
\hline & Skor Nertal Media Online & 2.2500 & 6 & .22361 & .09129 \\
\hline \multirow{2}{*}{$\begin{array}{l}\text { Pair } \\
2\end{array}$} & $\begin{array}{c}\text { Skor Observasi Pemanfaatan Media } \\
\text { Online }\end{array}$ & 2.7260 & 10 & .55302 & .17488 \\
\hline & Skor Netral Pemanfaatan Media Online & 2.275 & 10 & .2486 & .0786 \\
\hline
\end{tabular}

Hasil uji normalitas melalui uji Kolmogrof - Smirnov menunjukkan bahwa kedua kelompok data berdistrbusi normal, sehingga uji perbedaan menggunakan Uji t (T test). Hasil Uji statistik skor hasil observasi dan skor netral pada tabel 7 berikut.

Table 7. Hasil uji perbandingan skor hasil observasi dan skor netral respon terhadap media onlinea dan pemanfaatannya dalam pembelajaran 
Paired Samples Test

\begin{tabular}{|c|c|c|c|c|c|c|c|c|c|}
\hline & \multicolumn{5}{|c|}{ Paired Differences } & \multirow[b]{3}{*}{$t$} & \multirow[b]{3}{*}{$d f$} & \multirow{3}{*}{$\begin{array}{l}\text { Sig. }(2- \\
\text { tailed) }\end{array}$} \\
\hline & & \multirow{2}{*}{ Mean } & \multirow{2}{*}{$\begin{array}{c}\text { Std. } \\
\text { Deviation }\end{array}$} & \multirow{2}{*}{$\begin{array}{l}\text { Std. } \\
\text { Error } \\
\text { Mean }\end{array}$} & \multicolumn{2}{|c|}{$\begin{array}{l}\text { 95\% Confidence } \\
\text { Interval of the } \\
\text { Difference }\end{array}$} & & & \\
\hline & & & & & Lower & Upper & & & \\
\hline Pair 1 & $\begin{array}{l}\text { Skor Observasi - Skor } \\
\text { Nertal Media Online }\end{array}$ & .53500 & .59547 & .24310 & -.08991 & 1.15991 & 2.201 & 5 & .079 \\
\hline Pair 2 & $\begin{array}{l}\text { Skor Observasi - Skor } \\
\text { Netral Pemanfaatan Media } \\
\text { Online }\end{array}$ & .45100 & .36004 & .11386 & .19344 & .70856 & 3.961 & 9 & .003 \\
\hline
\end{tabular}

Dari hasil analisis pada table 7 nampak bahwa untuk perbedaan skor respon anak terhadap media online, dengan nilai $\mathrm{t}=2,201$ dan nilai signifikansi 0,079 maka dapat ditafsirkan skor respon terhadap media online hasil observasi berbeda secara signifikan pada taraf nyata 0,10 , artinya sekitar $90 \%$ anak berpeluang memberi respon positif terhadap media online. (penelitian lain yang mendukung statement media online berguna bagi anak, Kaplan 2010) Namun demikian jika menggunakan taraf nyata 0,05 maka rata-rata skor respon hasil observasi dari anak terhadap media online tidak berbeda secara signifikan dengan skor respon netral. Hal ini dimungkinkan peluang respon negatif anak terhadap media online serta akan berdampak terhadap aktivitas belajar mereka di luar sekolah. (Penelitian lain yang mendukung statement media online buruk bagi anak, Johny 2018).

Namun demikian untuk respon anak terhadap pemanfaatan media online dalam pembelajaran, dengan nilai $\mathrm{t}=3,961$ dan nilai signifikansi kurang dari 0,05 maka rata-rata skor respon hasil observasi berbeda secara signifikan dengan skor respon netral. Hal ini menunjukkan bahwa anak menunjukkan respon positif terhadap pemanfaatan media online dalam pembelajaran.

\section{KESIMPULAN}

Disepakati bahwa banyak pihak -terutama guru dan orang tua- yang menggaungkan bahwa media online mendistraksi belajar anak. Hal ini dengan mudah dideteksi dari kepemilikan smartphone. Meski demikian, kepemilikan smatphone hanya menunjukkan kemungkinan penggunaan media sosial dan bukan penggunaan yang berlebihan. Dengan memahami durasi aktivitas siswa, khususnya aktivitas belajar setelah sekolah, penelitian ini mengisi gap durasi 'wasting-time di media sosial' berdasarkan pengecualian aktivitas pembelajaran setelah sekolah.

Hasil penelitian menunjukkan bahwa kepemilikan Smartphone sangat mungkin memudahkan pembelajaran siswa, yang mengarah pada kesimpulan bahwa penggunaan Smartphone dalam kegiatan pembelajaran tidak serta merta dilarang. Larangan tersebut sedikit banyak berkontribusi pada kurangnya pemahaman tentang teknologi. Misalnya, ketika pandemi terjadi dan kegiatan belajar dipaksa online, banyak daerah pedesaan yang kikuk beradaptasi karena 'tidak terbiasa' mengakses internet. Namun, untuk mencegah 'gangguan belajar' karena Smartphone, penggunaan Smartphone untuk siswa sebaiknya diawasi oleh orang dewasa. Guru bertanggung jawab atas penggunaan Ponsel cerdas oleh siswa di waktu sekolah dengan memberikan pembelajaran online. Orang tua bertanggung jawab atas aktivitas siswa di luar sekolah termasuk akses media sosial.

\section{UCAPAN TERIMAKASIH}


Dalam melaksanakan penelitian ini, penulis berterimakasih pada pada pihak siswa, orang tua berserta sekolah SMP 1 Kabila, Gorontalo, yang menjadi sumber informasi penulis.

\section{DAFTAR PUSTAKA}

Kumar, N, Nagalla, R, Marwah, T. Singh, M. (2018) Sentiment dynamics in social media news channels. https://doi.org/10.1016/j.osnem.2018.10.004

Sreejesh S, Justin Paul, Carolyn Strong, Jose Pius (2020) Consumer response towards social media advertising: Effect of media interactivity, its conditions and the underlying mechanism. https://doi.org/10.1016/j.ijinfomgt.2020.102155

Papakyriakopoulos, O, dkk (2019) Political communication on social media: A tale of hyperactive users and bias in recommender systems. https://doi.org/10.1016/j.osnem.2019.100058. Online Social Networks and Media

Fana, C. dkk. (2020) Spatial biases in crowdsourced data: Social media content attention concentrates on populous areas in disasters. https://doi.org/10.1016/j.compenvurbsys.2020.101514

Woods, C, H. Scoot, H (2016) \#Sleepyteens: Social media use in adolescence is associated with poor sleep quality, anxiety, depression and low self-esteem. http://dx.doi.org/10.1016/j.adolescence.2016.05.008. Journal of Adolescence (51) p. 4149.

Fu, S., Li, H., Liu, Y., Pirkkalainen, H., Salo, M.. (2020). Social media overload, exhaustion, and use discontinuance: Examining the effects of information overload, system feature overload, and social overload. Information Processing and Management. https://doi.org/10.1016/j.ipm.2020.102307

Fang, J., Wang, X., Wen, Z., Zhou, J. (2020) Fear of missing out and problematic social media use as mediators between emotional support from social media and phubbing behavior. Addictive Behaviors. https://doi.org/10.1016/j.addbeh.2020.106430

Knapke, J. Haynes, E. and Breen, J (2016). Evaluation of Online Graduate Epidemiology Instruction and Student Outcomes. https://olj.onlinelearningconsortium.org/index.php/olj/article/view/737/236

Macmud, Karmila. 2018. The Smartphone Use in Indonesian Schools: The High School Students' Perspectives. Journal of Arts \& Humanities. Vol 07 Issue 03 2018: page 33-40. DOI: http://dx.doi.org/10.18533/journal.v7i3.1354

Adams, Mike. 2019. Threading the Cyber-Needle: Protecting Children by Banning Smartphone in School while Still Embracing Technology. 51 McGeorge L. Rev. 245 (2019-2020). https://heinonline.org/HOL/LandingPage?handle=hein.journals/mcglr51\&div=16\&id= \&page $=$

Kilis, S., \& Yildirim, Z. (2019). Posting patterns of students'social presence, cognitive presence, and teaching presence in online learning. Online Learning, 23(2), 179-195. doi:10.24059/olj.v23i2.1460 
Seminar Nasional Penelitian dan Pengabdian kepada Masyarakat Universitas Sang Bumi Ruwa Jurai Tahun 2020

Johnshoy, Q. dkk. (2020) Social media use following exposure to an acute stressor facilitates recovery from the stress response. https://doi.org/10.1016/j.physbeh.2020.113012 